\title{
Human Trafficking in the Context of Global Migration: Modern Manifestation of De Facto Slavery, Servitude and Forced or Compulsory Labour
}

\author{
Manisuli Ssenyonjo
}

In: (2021) 10(2) International Human Rights Law Review 191-215

\begin{abstract}
In recent years there has been a significant increase in trafficking in human beings as a global phenomenon. COVID-19 pandemic created conditions that increased the number of persons who were vulnerable to human trafficking and disrupted current and planned anti-trafficking initiatives. Human trafficking treats human beings as commodities to be bought and sold and put to forced labour often for lower or no payment. This constitutes a modern form of de facto slavery, servitude and forced or compulsory labour. This article provides an overview of international law on human trafficking and considers response to human trafficking in Africa. It further considers whether diplomats can be held accountable for exploitation of migrant domestic workers in receiving States. It further examines whether diplomatic immunity can be used as a bar to the exercise of jurisdiction by domestic courts and tribunals of a state which hosts the diplomat (the 'receiving state') in cases of employment of a trafficked person by a former or serving diplomat. It ends by considering whether trafficked persons should be held to bear individual criminal responsibility for crimes they have committed (or were compelled to commit) in the course, or as a direct consequence, of having been trafficked. Such crimes may include unlawful entry into, presence or residence in another country of transit or destination, working without a work permit, sex work, and use of false identity/false passport.
\end{abstract}

https://doi.org/10.1163/22131035-10020006 